\title{
A first description of ciliate assemblages in a subtropical, eutrophic bay, South China Sea: species assemblage and environmental correlates
}

\section{Ciliate variation in a subtropical bay}

\author{
Huaxue LIU ${ }^{1, a}$, Mianrun CHEN ${ }^{2}$, Pingping $\operatorname{SHEN}^{3}$, Honghui HUANG $^{1, a}$, Ming DAI ${ }^{1}$ and Zhanhui QI ${ }^{1}$ \\ 1 Guangdong Provincial Key Laboratory of Fishery Ecology and Environment, Key Laboratory of South China Sea Fishery Resources \\ Exploitation \& Utilization, Ministry of Agriculture, South China Sea Fisheries Research Institute, Chinese Academy of Fisheries Sciences, \\ Guangzhou 510300, P.R. China \\ 2 South China Sea Institute of Planning and Environmental Research, South China Sea Branch, SOA, Guangzhou 510310, P.R. China \\ 3 Key Laboratory of Tropical Marine Bio-resources and Ecology, South China Sea Institute of Oceanology, Chinese Academy of Sciences, \\ Guangzhou 510301, P.R. China
}

Received 27 February 2016; Accepted 5 September 2016

\begin{abstract}
The ciliate community together with physical-chemical variables was investigated in a subtropical, eutrophic bay of the South China Sea from January 7-10 (dry season) and April 27-30 (wet season), 2012. Both temperature and salinity exhibited typical seasonality. A total of 27 species of ciliates belonging to 19 genera were identified, and the dominant species were Strombidium globosaneum in January and Codonella rapa in April. The composition and abundance exhibited spatial and temporal fluctuations, with total mean abundance of ciliates in April $\left(1219 \pm 919\right.$ ind $\left.\mathrm{l}^{-1}\right)$, was much higher than that in January $\left(283 \pm 137\right.$ ind $\left.\mathrm{l}^{-1}\right)$. Spatially, high species numbers were found mainly near the mouth of the estuary, and the abundance decreased from inside to the mouth of the bay. Statistical analysis showed that ciliate assemblages were closely related to the environmental variables. The distribution patterns of salinity and chlorophyll $a$ concentration were similar, suggesting that, prey abundance may correlate significantly with ciliate abundance, and salinity may not be the main factor explaining the spatial variation in the ciliate community in the study area.
\end{abstract}

Keywords: Ciliates / environmental change / eutrophic / Maowei Sea

\section{Introduction}

Ciliates are globally distributed and episodically dominate ciliate microzooplankton community. Both theoretical and field studies of oceanic food-web dynamics indicate that they are capable of consuming a significant proportion of primary production (Dolan and Gallegos 2001), especially picoplankton (e.g., bacteria, Prochlorococcus and Synechococcus) and nanoplankton (Chen et al. 2010). The consumption of ciliates comprises about $30 \%$ of the daily carbon rations of many copepod species (Calbet and Saiz 2005). Therefore ciliates are a major tropic link between the microbial food web and grazing food chain (Pierce and Turner 1992).

Many factors can affect the composition and abundance of ciliates either directly or indirectly such as copepods by their predatory feeding. Jyothibabu et al. (2006) and Urrutxurtu

\footnotetext{
a Corresponding author:

liuhuaxue@scsfri.ac.cn; huanghh@scsfri.ac.cn
}

(2004) demonstrated that salinity is an important factor that controls the distribution of ciliates in Indian estuaries and the Nervión River estuary. Riverine runoff can trigger a shift of phytoplankton abundance and composition, and thereby affect the ciliates as food concentration and quality change (Dolan and Gallegos 2001).

Despite the importance of ciliates in global marine microbial food webs and grazing food chains, studies of the ciliates of the South China Sea (SCS) were started only in recent years (Tan et al. 2010; Liu et al. 2013), and the understanding of their distribution and variation in the SCS and adjacent area is minimal, in particular in the estuarine and bays. Therefore, the aim of this study was to investigate the spatio-temporal variations of the ciliates in a subtropical bay and to evaluate the impact of both human-caused eutrophication and natural runoff on the ciliate community in the SCS adjacent area, gaining insight about the regulating mechanisms of ciliate community structure under eutrophic conditions. 


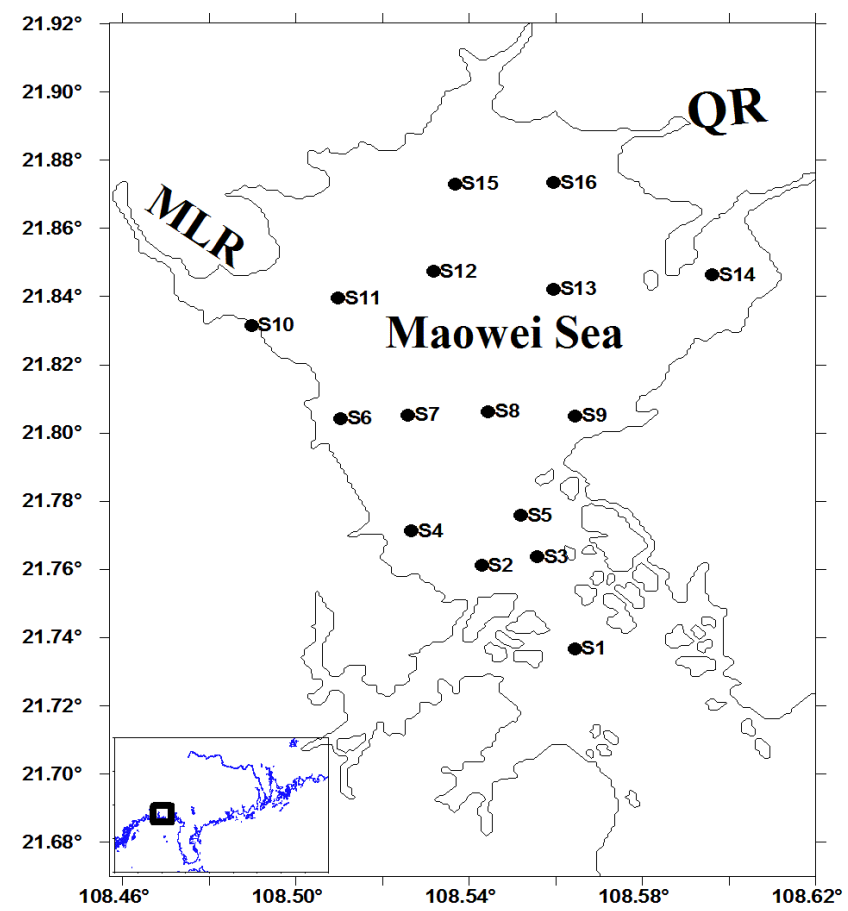

Fig. 1. The location of sampling sites in the Maowei Sea. MLR (Maoling Jiang River), QR (Qin Jiang River).

\section{Materials and methods}

\section{Study area}

The Maowei Sea (MWS) is a semi-enclosed shallow bay, with an area of about $135 \mathrm{~km}^{2}$ and a water depth of less than $10 \mathrm{~m}$. It is located in the northwestern part of the SCS and receives freshwater inflow from the Qinjiang River and Maoling River, which characterizes this bay as a typical estuary (Fig. 1). As a subtropical area, the area is significantly influenced by South-west monsoons in summer and North-east monsoons in January, with nearly $20 \%$ of river discharge occurring during January and $80 \%$ during summer. In addition, the rapid economic development around this area has brought about environmental stressors (e.g., anthropogenic drainage and oyster aquaculture in excess) on this bay ecosystem, resulting in eutrophication and frequent harmful algal blooms (Lan et al. 2014).

\section{Field sampling and data analyses}

From January 7-10 (dry season) and April 27-30 (wet season), 2012, field sampling was conducted at 16 sites (Fig. 1). Seawater samples in the surface layer $(0.5 \mathrm{~m}$ depth $)$ were collected using a 5.0-L GO FLO bottle, and Secchi disk depth (SD) was measured. Temperature and salinity were measured using a YSI 6600 multi-parameter water quality monitor (Yellow Aprils Inc.) at each sampling site. After collection, seawater samples for dissolved inorganic nutrient (i.e., nitrate, nitrite, ammonia, phosphate and silicate) determination were filtered through $0.45 \mu \mathrm{m}$ cellulose filters and preserved at $-20{ }^{\circ} \mathrm{C}$ in the dark before further processing in the laboratory
The nutrient concentrations were determined according to the method described in Yin et al. (2004). Seawater samples for total chlorophyll $a\left(\mathrm{Chl} a=\mathrm{mg} \mathrm{m}^{-3}\right)$ were filtered through $0.45 \mu \mathrm{m} \mathrm{GF} / \mathrm{F}$ filters, and the concentrations were measured by a Turner Designs 10-AU fluorometer according to Parsons et al. (1984).

To enumerate ciliates, one liter of seawater was fixed with Lugol's solution (neutral) and stored in darkness for later analyses. Each sample was concentrated to 20-30 mL using the Utermöhl method (1958), and the ciliates were identified under a microscope referring to Kofoid and Campbell (1929 1939), Carey (1992) for tintinnids and Maeda and Carey (1985), and Lynn et al. (1991) for aloricate ciliates.

\section{Statistical analysis}

The number of species and ciliate abundance were calculated for each sample. The ciliate community structure was studied by calculating the species diversity $\left(H^{\prime}\right)$, evenness $\left(J^{\prime}\right)$, and richness $(d)$ of samples according to the following formulas:

$$
\begin{aligned}
H^{\prime} & =\sum_{i=1}^{S} P i(\operatorname{Ln} P i) \\
J^{\prime} & =H^{\prime} / \operatorname{Ln} S \\
d & =(S-1) / \ln N
\end{aligned}
$$

where $P i$ is defined as the proportion of the total count arising from theith species, $S$ is the total number of species, $n_{i}$, is the abundance of the $i$ th species, and $N$, is the total number of individuals.

Multivariate analyses of spatial variations in the ciliate communities were analyzed using the Primer v5.0 software package. Bray-Curtis similarity matrices were computed on fourth-root-transformed ciliate abundance data, and the Euclidean distance matrix was computed on $\log (x+1)$ transformed environmental data, including Chl $a$. A Spearman correlation analysis between ciliates communities and environmental factors was computed by the SPSS v20.0 statistical program (Jiang et al. 2011). The abundance of species and the environmental factors were used and a canonical correspondence analysis (CCA) analysis was performed using statistical program CANOCO version 4.5 (Chen et al. 2011) to gain insight into the spatial correspondence of the distribution of ciliates in relation to environmental variables.

\section{Results and discussion}

\section{Environmental factors}

Sea surface temperature (T) and salinity (S) exhibited typical seasonality with the average temperature much higher in April $\left(25.40^{\circ}\right)$ than in January $\left(11.09^{\circ}\right)$, while salinity was higher in January (22.85) compared to April (16.15) (Table 1). Influenced by freshwater inputs from the two rivers, the spatial fluctuation of salinity (the maximum value minus the minimum value) reached about 10 and 18 in January and in April, 
Table 1. Comparison of environmental parameters in sea surface water between two seasons. (Data are spatial averaged with the range)

\begin{tabular}{ccccccc}
\hline \multirow{2}{*}{ Parameters } & \multicolumn{3}{c}{ January } & \multicolumn{3}{c}{ April } \\
\cline { 2 - 7 } & Min & Max & Mean $\pm \mathrm{sd}$ & Min & max & Mean $\pm \mathrm{sd}$ \\
\hline DIN $\left(\mu \mathrm{mol} \mathrm{l}^{-1}\right)$ & 10.42 & 22.99 & $15.60 \pm 3.76$ & 22.22 & 44.12 & $29.54 \pm 6.74$ \\
Phosphate $\left(\mu \mathrm{mol} \mathrm{l}^{-1}\right)$ & 0.37 & 4.37 & $1.37 \pm 1.07$ & 0.26 & 0.87 & $0.50 \pm 0.18$ \\
SS $\left(\mathrm{mg} \mathrm{l}^{-1}\right)$ & 20.80 & 42.60 & $29.60 \pm 6.89$ & 23 & 34.80 & $27.33 \pm 3.19$ \\
SD $(\mathrm{m})$ & 0.50 & 1.80 & $0.97 \pm 0.43$ & 0.50 & 1.50 & $1.01 \pm 0.30$ \\
\hline
\end{tabular}

Abbreviation: DIN (Dissolved inorganic nitrogen), Chl $a$ (chlorophyll $a$ ), SS (suspended solids), SD (Secchi depth).
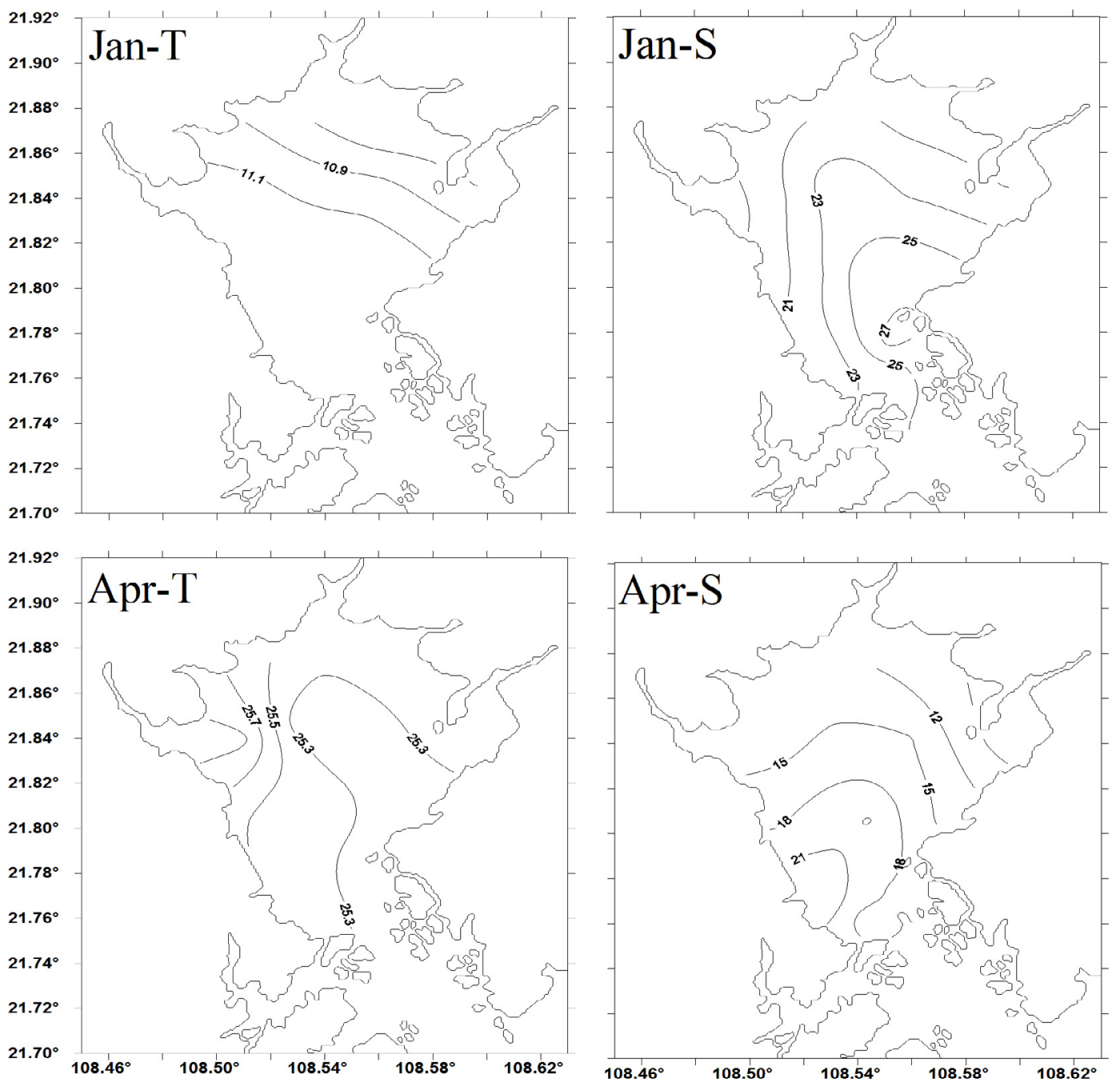

Fig. 2. Spatial and temporal distributions of temperature (T) and salinity (S) in the MWS in April and January.

respectively (Fig. 2), indicating a sharper gradient in April than in January. In winter, salinity at most stations was higher than 20, except at station S10 which is located near the MLR mouth, while in April, salinity at half the sites was lower than 16 (Fig. 2).

The Secchi depth (SD) in the MWS showed no substantial seasonal variation with values ranging between $0.5-1.8 \mathrm{~m}$ in January and $0.5-1.5 \mathrm{~m}$ in April. The MWS was typically nutrient-rich with dissolved inorganic nitrogen (DIN) ranging from 10.42 to $44.12 \mu \mathrm{mol} \mathrm{l^{-1 }}$ and phosphate concentrations ranging between 0.26 and $4.37 \mu \mathrm{mol} \mathrm{l}^{-1}$. Spatially, high nutrient concentrations were usually found in the estu- ary (e.g. stations S10 and S14). Temporally, the mean ( \pm s.d.) concentration of DIN in April $\left(29.54 \pm 6.74 \mu \mathrm{mol} 1^{-1}\right)$ was higher than in January $\left(15.60 \pm 3.76 \mu \mathrm{mol}^{-1}\right)$, while that for phosphate concentrations showed an opposite trend with April $\left(0.50 \pm 0.18 \mu \mathrm{mol} \mathrm{l}^{-1}\right)$ significantly lower than in January $\left(1.37 \pm 1.07 \mu \mathrm{mol}^{-1}\right)$. A temporal fluctuation of Chl $a$ content was as obvious as that of spatial variation as the maximum Chl $a$ concentrations were all found near the river mouth in January (station S10 near the MLR: $4.86 \mathrm{mg} \mathrm{m}^{-3}$ ) and in April (S14 at the QR: $\left.3.68 \mathrm{mg} \mathrm{m}^{-3}\right)$, whereas the minimum (0.61 and 1.39 in April and January, respectively) occurred near the bay mouth (Fig. 3). 

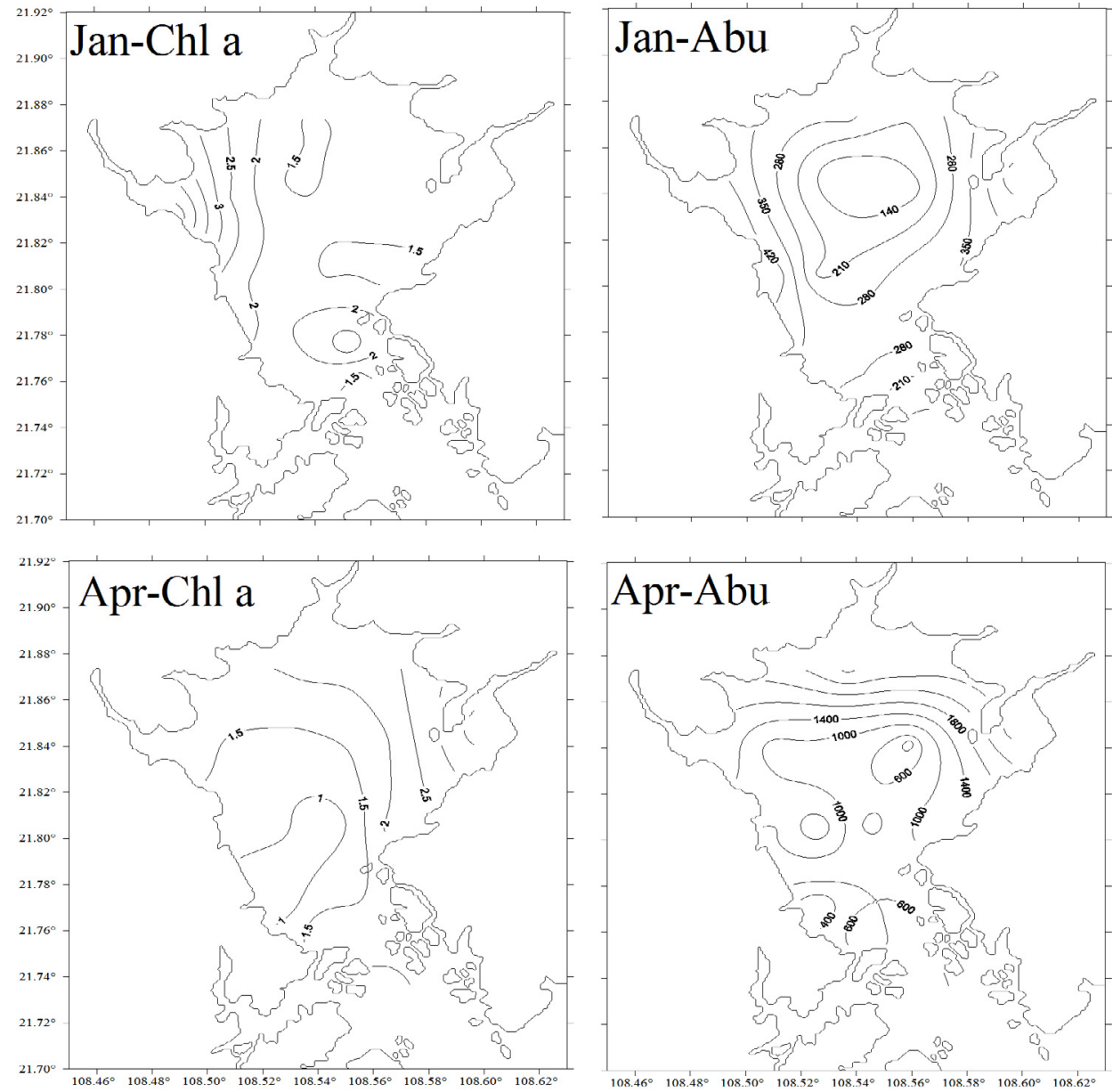

Fig. 3. Spatial and temporal distributions of total chlorophyll $a(\mathrm{Chl} a)$ and ciliate abundance (Abu) in the MWS in April and January.

\section{Taxonomic structure and species distribution}

A total of 27 ciliates species belonging to 19 genera were identified during the study period (Table 2a), among which 10 species were tintinnids. Tintinnids that have a lorica into which the ciliate cell can withdraw, occur in the oceans worldwide (Dolan and Gallegos 2001). The dominant species were Codonella rapa, Mesodinium rubrum, Strombidium globosaneum, Strombidium. conicum and Tintinnopsis minuta. In January, the ciliates were numerically dominated by strombidiids (Figs. 4 and 5) including S. globosaneum (stations S4 and S10) and S. conicum (stations S14 and S15), and occasionally by $C$. rapa at stations S5 and S8. The community in April was primarily composed of tintinnids (Figs. 4 and 5), and the dominant species were C. rapa, S. globosaneum, S. conicum and $M$. rubrum, respectively.

\section{Spatial and temporal patterns of planktonic ciliate communities}

The species richness and diversity at each station ranged from 3 to 7 and 1.30 to 2.75 , with high species number and diversity occurring near the river mouth (e.g., S10 and S14). Spatially, the total abundance also decreased from the estuary towards the bay mouth (Fig. 3). Temporally, the abundance at most stations was lower than 500 ind $1^{-1}$ in January, and higher than 500 ind $1^{-1}$ in April (Fig. 3). The mean abundance in April $\left(1219 \pm 919\right.$ ind $\left.1^{-1}\right)$ was much higher than that in January $\left(283 \pm 137\right.$ ind $\left.1^{-1}\right)$. In both April and January, a high abundance of cells was found near the river mouth (such as stations S14 and S15) and tintinnid and strombidiid ciliates were the first two groups numerically (Fig. 5). The dominant species indicated seasonality with $C$. rapa most abundant in April and S. globosaneum in January. The species diversity and abundance of ciliates varied greatly among the stations and between the two seasons (Fig. 6). Bray-Curtis similarities from log-transformed ciliate species-abundance data revealed that the spatial pattern of ciliate communities was closely related to the environmental variables.

The ciliate community showed striking seasonal variations with the abundance in April much higher than in January. Compared to other eutrophic coastal areas, ciliate diversity and abundance in the MWS were at a relatively low level, especially in January (dry season). Previous studies showed that total ciliate abundance in the inner-shelf waters near the Taiwan Strait were between 823 to 1296 ind $1^{-1}$ in summer (Chen et al. 2012), and the mean ciliate abundances in Bay of Blanes (Vaque et al. 1997) and Kuryongpo Harbor (Kim et al. 2007) were generally higher than 2000 ind $1^{-1}$. This striking 


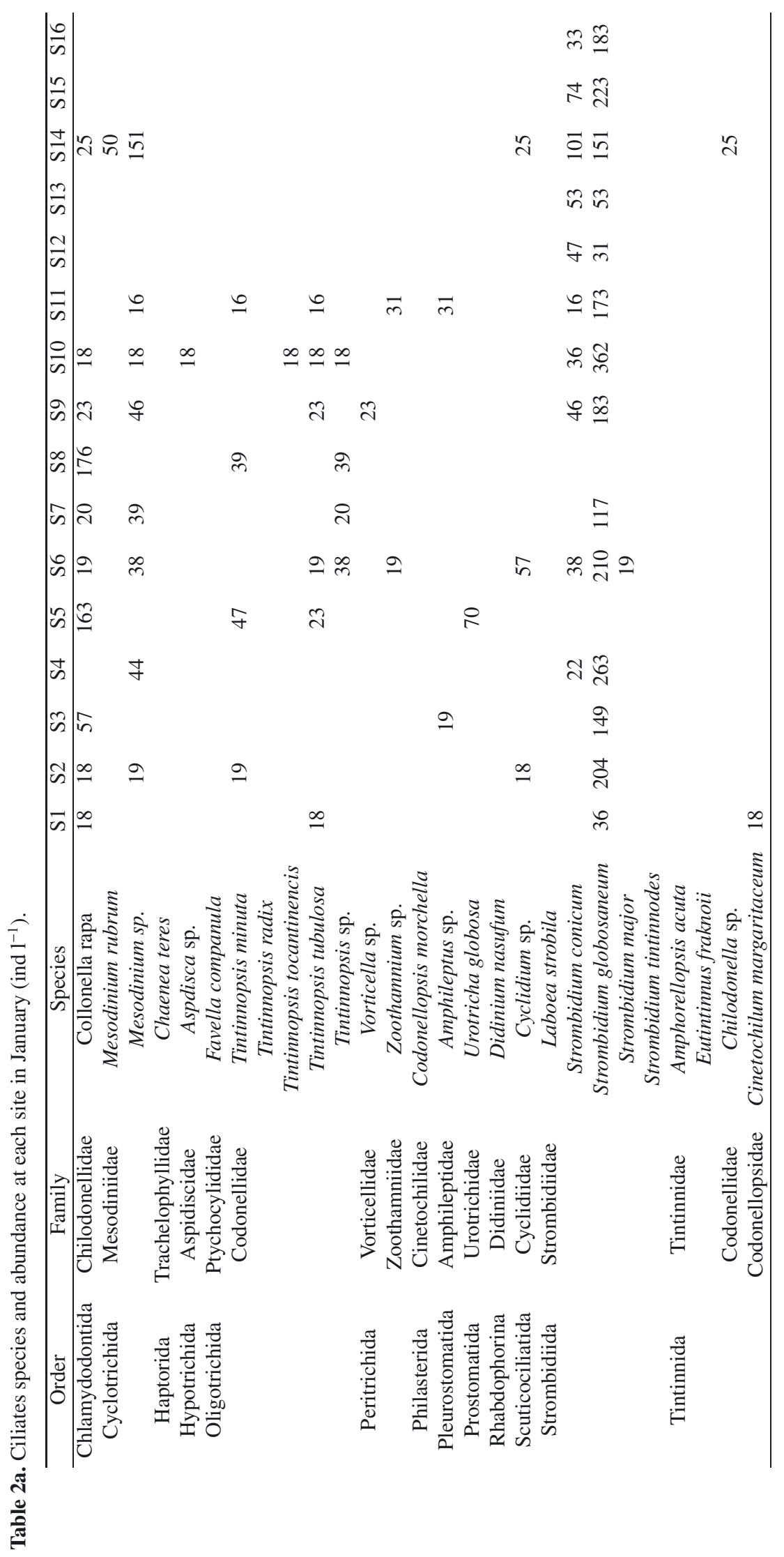




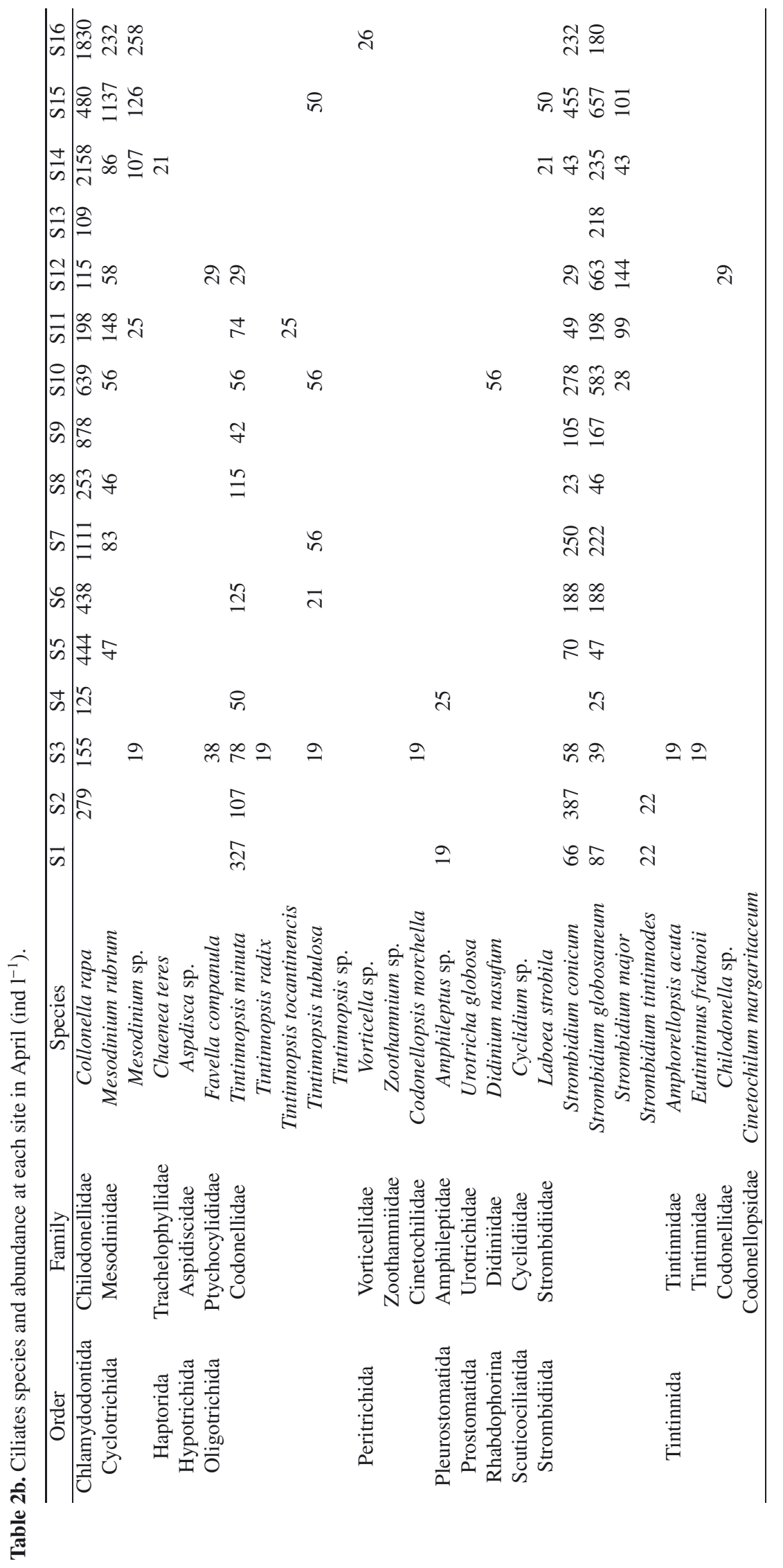


Table 2c. Correlation between environmental variables and abundance $(A b u)$, species number $(S)$, species diversity $\left(H^{\prime}\right)$, species evenness $\left(J^{\prime}\right)$ and species richness $(d)$ of the ciliate community.

\begin{tabular}{cccccccc}
\hline Parameters & SST & SSS & SD & SS & DIN & PO4 & Chl $a$ \\
\hline$A b u$ & $0.60^{* *}$ & $-0.80^{* *}$ & -0.19 & -0.03 & $0.81^{* *}$ & -0.25 & 0.27 \\
$S$ & 0.29 & $-0.50^{* *}$ & -0.08 & 0.14 & $0.45^{*}$ & 0.33 & $0.40^{*}$ \\
$H^{\prime}$ & 0.26 & -0.18 & 0.08 & 0.07 & 0.23 & 0.11 & 0.00 \\
$J^{\prime}$ & -0.12 & $0.40^{*}$ & 0.19 & 0.10 & -0.33 & 0.18 & $-0.42^{*}$ \\
$d$ & 0.13 & -0.31 & -0.07 & 0.22 & 0.25 & $0.45^{*}$ & $0.38^{*}$ \\
\hline
\end{tabular}

$* *: p<0.01 ; *: p<0.05$.

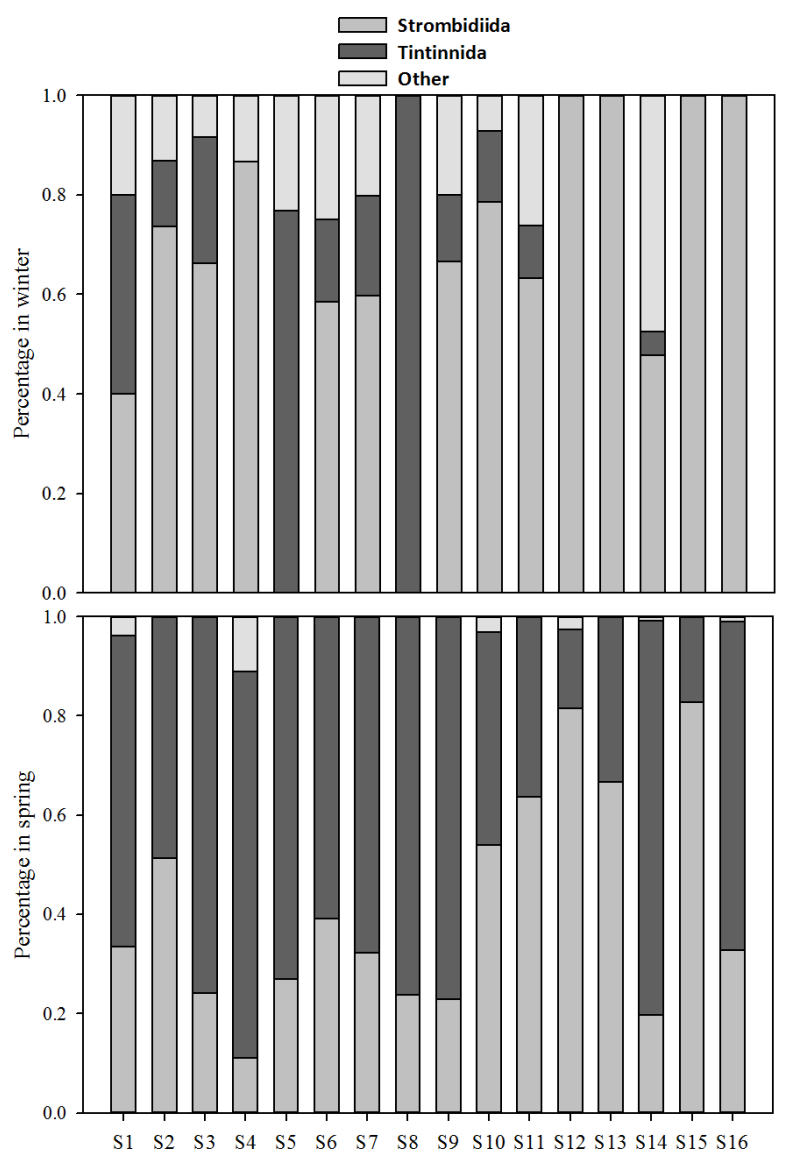

Fig. 4. Percentage of different ciliate groups in the MWS in April and January.

difference might be correlated with the different ambient factors; the estuary ecosystem in the MWS has strong gradients in environmental variables characterized by unique composition and abundance of ciliates. Also, riverine runoff can trigger a shift of phytoplankton abundance and composition, which thereby affects the ciliates as food changes indirectly (Dolan and Gallegos 2001; Shen et al. 2011).

\section{Relationships between ciliates and environmental parameters}

Spearman correlations between environmental variables and ciliate species number, abundance, diversity, evenness and richness are summarized in Table 2c. Ciliate abundances were significantly and positively correlated with SST and DIN, but negatively correlated with SSS $(p<0.01)$. Ciliate species number was also significantly negatively correlated with SSS $(p<0.01)$. The cumulative percentages of explained variance and correlation coefficients of each selected factor for the two main axes are shown in the CCA analysis (Fig. 7). The two main axes cumulatively explained $62.6 \%$ and $72.7 \%$ of the variation in the ciliate spatial distribution in January and April, respectively. In January, SD and salinity were the main determinants for the spatial distribution of ciliates (Fig. 7). In April, SD was the main determinant for the spatial distribution, followed by salinity, DIN and Chl $a$ concentration. Results of CCA analysis also revealed that $C$. rapa was closely related to high salinity and SD, while $S$. globosaneum was negatively related to salinity and SD.

Salinity and SD were influenced by freshwater input, which carried nutrients and stimulated phytoplankton growth. No significant correlation between ciliates abundance and total Chl $a$ concentration was found. Ciliates prefer pico- and nano-phytoplankton, while total $\mathrm{Chl} a$ concentration does not reveal the size-fractionated structure of phytoplankton. Thus, our measure of total phytoplankton biomass ( $\mathrm{Chl} a$ ) was a limitation of this study.

\section{Driving force of ciliate community change?}

In temperate regions, Kim et al. (2007) indicated that a temporal shift of dominant ciliate species was closely related to environment changes, especially the temperature in a harbor of the eastern coast of Korea. Higher temperature was suitable for the growth of pico-phytoplankton which likely led to the high ciliate abundance in April. In January, low temperature was assumed to be out of range for survival of some species of ciliates and phytoplankton (Lan et al. 2014), which consequently led to a low abundance due to both high mortality and insufficient Chl $a$ concentrations in the Maowei Sea. However, despite the large difference between the total abundance in April and January, multivariate analysis (CCA) did not detect any significant effect of the temperature on seasonal variation in ciliate abundance. In subtropical areas, the temperature fluctuation is not as high as that in temperate regions and therefore, salinity, light availability and other physical factors might play a more important role in controlling the planktonic community.

Among the numerous physical gradients, salinity is thought to be the main factor responsible for the variations 

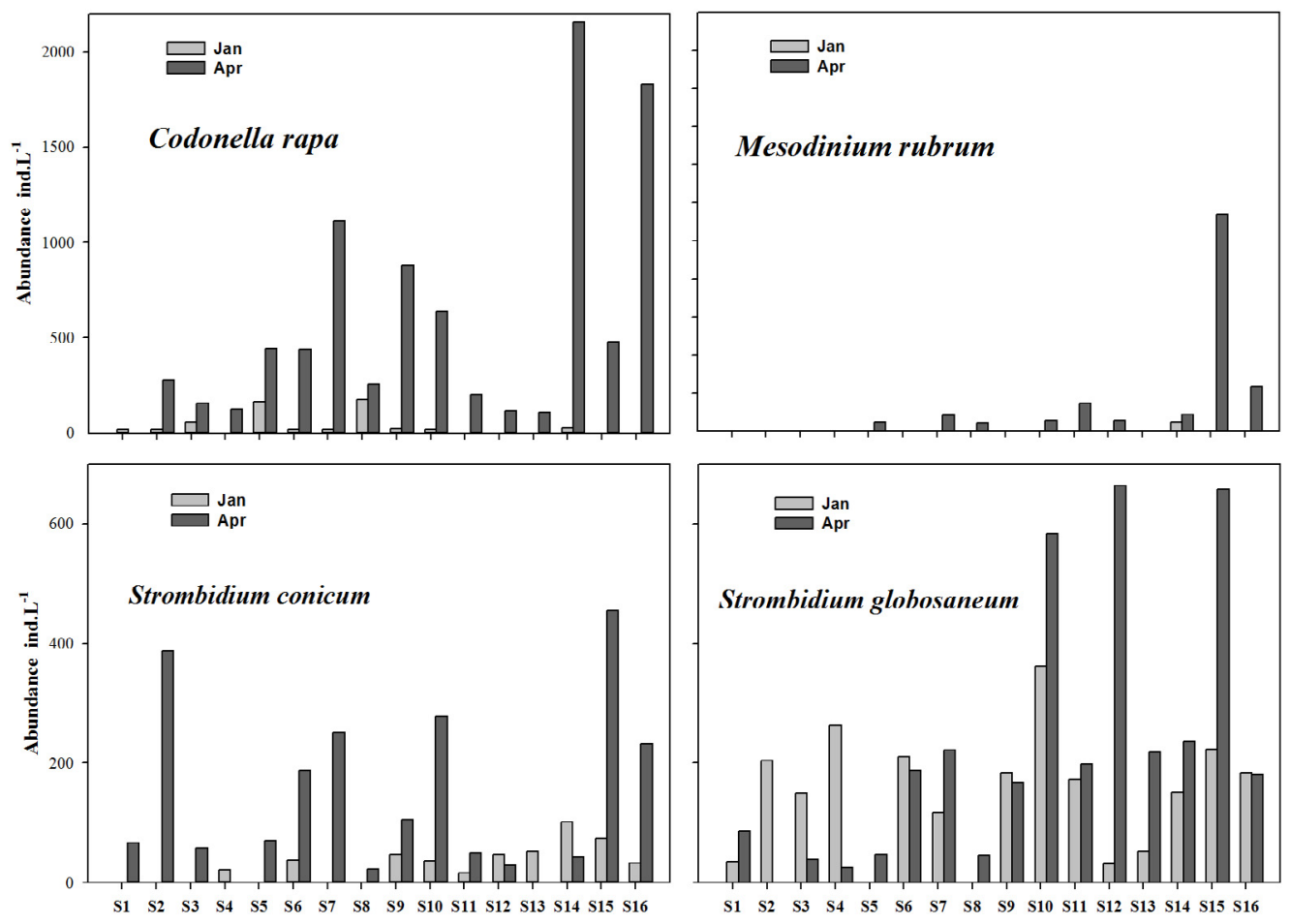

Fig. 5. Abundance of dominant species in the MWS in April and January.

in ciliate communities in estuaries and has been intensively studied worldwide (Urrutxurtu 2004; Jyothibabu et al. 2006). In our study, salinity fluctuated among stations and between seasons, while the high abundances of ciliates were found in the river mouth where lower salinity usually occurred. These findings are consistent with the results of Jyothibabu et al. (2006) and Urrutxurtu (2004). However, we cannot confirm that salinity is the most important environmental factor that controls the distribution of ciliates in MWS, as $C$. rapa abundance is correlated with different variables at two sampling times - Chl $a$, DIN and SS in April, and negative SST in January (Fig. 4). SD was usually lower than $2.0 \mathrm{~m}$ in the MWS, revealing low light transmittance and likely unfavorable conditions for phytoplankton photosynthesis. As seawater samples at surface water $(0.5 \mathrm{~m})$ were collected in this study, and the minimum value of SD was $0.5 \mathrm{~m}$ (Table 1$), \mathrm{SD}$ may not be a main factor for variation of ciliates.

Biological factors such as copepod predation, species competition and Chl $a$ concentration also play an important role in controlling ciliate assemblages (Johansson et al. 2004). Among them, Chl a concentrations, particularly pico- and nanoplankton might be the most important factors in controlling the spatial distribution of the ciliate community (Chen et al. 2012). Large variations in salinity occurred in January and April (Fig. 2) and as a consequence, might occur large variations in pico- and nanoplankton abundance in MWS. The patterns of salinity and Chl $a$ concentration were similar, and based on these observations we believe that phytoplankton prey abundance may have been related to ciliate abundance, and that salinity may not be the main factor explaining the spatial variations in the ciliate community. Moreover, Chl $a$ con-
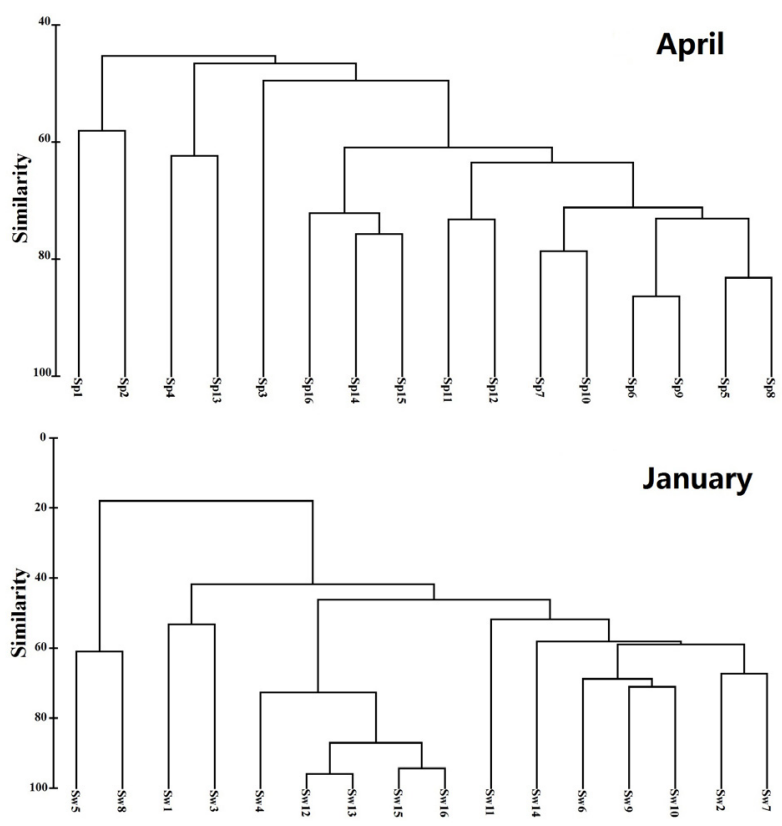

Fig. 6. Cluster analysis for taxonomic patterns of ciliate communities on Bray-Curtis similarities for species-abundance data in MWS.

centration is not a sufficient parameter to represent ciliates nutrition, as phytoplankton species composition also influences ciliate nutrition. As a result, more detailed studies need to be conducted in the future. 



Fig. 7. Canonical correspondence analysis of the spatial distribution of ciliates in January and April.

\section{Conclusion}

The ciliate community of the Maowei Sea was dominated by Codonella rapa, Strombidium globosaneum, Strombidium conicum and Mesodinium rubrum in April and January 2012. Spatial and seasonal variations in ciliate abundances were correlated with some physical factors but not $\mathrm{Chl} a$ concentration. Due to the lack of direct evidence of food sources for ciliates in the MWS, both field investigation and laboratory research need to be done in the future.

Acknowledgements. The authors thank Prof. Darcy Lonsdale and Dr. Liu Weiwei for their help with the manuscript. The authors are also grateful to the three anonymous reviewers who helped to amend the manuscript. This research was supported by the financial fund of National Basic Research Program of China (973 Program,
2015CB452904), NSFC (41306168) and Special Fund for Agroscientific Research in the Public Interest (201403008).

\section{References}

Calbet A., Saiz E., 2005. The ciliate-copepod link in marine ecosystems. Aquatic Microbial Ecology 38, 157-167.

Carey P.G., 1992. Marine Interstitial Ciliates. London: Chapman \& Hall 14-324.

Chen B.Z., Liu H.B., Lau M.T.S., 2010. Grazing and growth responses of a marine oligotrichous ciliate fed with two nanoplankton: Does food quality matter for micrograzers? Aquatic Ecology 44, 113-119.

Chen J.Y., Tsai A.Y., Gong G.C., Chiang K.P., 2012. Grazing Pressure by Ciliates on the Nanolagellate Community in a Subtropical Pelagic Continental Shelf Ecosystem: Small Ciliates (of $<45 \mu \mathrm{m}$ ) are Major Consumers of the Nanolagellate Community. Zoological Studies 51, 1308-1318.

Chen M.R., Chen B.Z., Harrison P., Liu H.B., 2011. Dynamics of mesozooplankton assemblages in subtropical coastal waters of Hong Kong: A comparative study between an eutrophic estuarine and a mesotrophic coastal site. Cont. Shelf Res. 31, 1075-1086.

Dolan J.R., Gallegos C., 2001. Estuarine diversity of tintinnids (planktonic ciliates). Journal of Plankton Research 23, 1009 1027.

Elliot M., McLusky D.S., 2002. The need for definitions in understanding estuaries. Estuarine, Coastal and Shelf Science 55, 815827.

Jiang Y., Xu H., Hu X., Zhu M., Al-Rasheid K.A.S., Warren A., 2011. An approach to analyzing spatial patterns of planktonic ciliate communities for monitoring water quality in Jiaozhou Bay, northern China. Marine Pollution Bulletin 6, 227-235.

Johansson M., Gorokhova E., Larsson U., 2004. Annual variability in ciliate community structure, potential prey and predators in the open northern Baltic Sea proper. Journal of Plankton Research $26,67-80$.

Jyothibabu R., Madhu N.V., Jayalakshmi K.V., Balachandran K.K., Shiyas C.A., Martin G.D., Nair K.K.C., 2006. Impact of freshwater influx on microzooplankton mediated food web in a tropical estuary (Cochin backwaters-India). Estuarine, Coastal and Shelf Science 69, 505-518.

Kim Y.O., Chae J., Hong J.S., Jang P.G., 2007. Comparing the distribution of ciliate plankton in inner and outer areas of a harbor divided by an artificial breakwater. Marine Environmental Research 64, 38-53.

Kofoid C.A., Campbell A.S., 1929. A conspectus of the marine and freshwater ciliata belonging to the suborder Tintinoinea, with descriptions of new species principally from the agassiz expedition to the eastern tropical pacific. Univ. Calif. Pub. Zool, pp. 1-403.

Kofoid C.A., Campbell A.S., 1939. The ciliata: the Tintinnoinea. Bull. Mus. Comp. Zool, pp. 1-473.

Lan W.L., Li T.S., Zheng X.Q., Shi X.F., Li M.M., Li M.M., Li B., 2014. The structure and distribution of phytoplankton community in the Qinzhou Bay during dry season. Acta Oceanologica Sinica 36, 122-129.

Liu H.X., Li G., Tan Y.H., Ke Z.X., Huang J.R., Huang L.M., 2013. Latitudinal changes $\left(6^{\circ} \mathrm{S}-20^{\circ} \mathrm{N}\right)$ of summer surface ciliates abundance and species compositions in surface waters from the Java Sea to the South China Sea. Acta Oceanologica Sinica 32, 66-70.

Lynn D.H., Roff J.C., Hopcroft R.R., 1991. Annual abundance and biomass of aloricate ciliates in tropical neritic waters off Kingston. Jamaica Mar. Biol. 110, 437-448. 
Maeda M., Carey P.G., 1985. An illustrated guide to the species of the family Strombidiidae (Oligotrichida, Ciliophora), free swimming protozoa common in the marine environment. Bulletin of the Ocean Research Institute University of Tokyo 19, 1-68.

Parsons T.R., Maita Y., Lalli C.M., 1984. A manual of chemical and biological methods for seawater analyses. Pergamon Press, Oxford, p. 173.

Pierce R.W., Turner J.T., 1992. Ecology of planktonic ciliates in marine food webs. Reviews in Aquatic Sciences 6, 139-181.

Shen P.P., Li G., Huang L.M., Zhang J.L., Tan Y.H., 2011. Spatiotemporal variability of phytoplankton assemblages in the Pearl River estuary, with special reference to the influence of turbidity and temperature. Continental Shelf Research 31, 1672-1681.

Tan Y.H., Huang L.M., Huang X.P., Su Q., Shi X., Huang J.R., 2010. The relationships between ciliate composition, abundance, and environmental factors in Sanya Bay coral reef waters. Acta Ecologica Sinica 30, 6835-6844.
Urrutxurtu I., 2004. Seasonal succession of tintinnids in the Nervión River estuary, Basque Country, Spain. Journal of Plankton Research 26, 307-314.

Utermohl H., 1958. Zurvervolkommungder quantitativen phytoplankton Methodik. Mitteilungen der Internationale Vereinigung fur Theoretische und Angewandte. Limnologie 9, 1-38.

Vaque D., Bloughl H.A., Duarte C.M., 1997. Dynamics of ciliate abundance, biomass and community composition in an oligotrophic coastal environment (NW Mediterranean). Aquatic Microbial Ecology 12, 71-83.

Yin K.D., Zhang J.L., Qian P.Y., Jian W.J., Huang L.M., Chen J.F., 2004. Effect of wind events on phytoplankton blooms in the Pearl River Estuary during summer. Continental Shelf Research 24, 1909-1923. 